Research article

Open Access

\title{
Antioxidative and Antiinflammatory Activities of the Chloroform Extract of Ganoderma lucidum Found in South India
}

\author{
Soniamol Joseph ${ }^{1}$, Baby SABUlaL ${ }^{1}$, Varughese GeORge ${ }^{1,3}$, \\ Thozhuthumparambal P. SMINA ${ }^{2}$, Kainoor K. JANARDHANAN * 2
}

\footnotetext{
${ }^{1}$ Phytochemistry and Phytopharmacology Division, Tropical Botanic Garden and Research Institute, Palode, Thiruvananthapuram - 695 562, India.

${ }^{2}$ Amala Cancer Research Centre, Amala Nagar, Thrissur - 680 555, India.

${ }^{3}$ Amity Institute for Herbal \& Biotech Products Development, Mannamoola, Peroorkada, Thiruvananthapuram - 695 005, India.

* Corresponding author. E-mail: kkjanardhanan@yahoo.com (K. K. Janardhanan)
}

Sci Pharm. 2009; 77: 111-121

doi:10.3797/scipharm.0808-17

Published: $\quad$ January $30^{\text {th }} 2009$

Accepted: January $30^{\text {th }} 2009$

Received: $\quad$ August $25^{\text {th }} 2008$

This article is available from: http://dx.doi.org/10.3797/scipharm.0808-17

(C) Joseph et al.; licensee Österreichische Apotheker-Verlagsgesellschaft m. b. H., Vienna, Austria.

This is an Open Access article distributed under the terms of the Creative Commons Attribution License (http://creativecommons.org/licenses/by/3.0/), which permits unrestricted use, distribution, and reproduction in any medium, provided the original work is properly cited.

\begin{abstract}
Antioxidative and anti-inflammatory activities of Ganoderma lucidum (Curt.: Fr.) P. Karst. (Aphyllophoromycetideae) from tropical South India were investigated. The chloroform extract of the mushroom showed marked free radical scavenging activities. The anti-inflammatory activity of the extract at concentrations of 100 and $50 \mathrm{mg} / \mathrm{kg}$ was evaluated in carrageenan induced acute and formalin induced chronic inflammatory models in mice. The extract showed remarkable antiinflammatory activity in both models, comparable to the standard reference drug diclofenac. The results suggest that anti-inflammatory activity of the chloroform extract of G. lucidum is possibly attributed to its free radical scavenging properties. This study also reveals the potent therapeutic uses of G. Iucidum from South India.
\end{abstract}

\section{Keywords}

Medicinal mushrooms • Ganoderma lucidum • Chloroform extract • Antioxidative activity • Antiinflammatory activity 


\section{Introduction}

Mushrooms represent a major and as yet largely untapped source of potent pharmaceutical products. Nearly 10,000 mushroom species are known, of which 2000 are safe for humans and about 300 of them possess medicinal properties. Ganoderma Iucidum, has been used in folk medicine in China and Japan for over 2000 years for a wide range of ailments. In Chinese folklore, fruiting bodies of Ganoderma have been regarded as a panacea for all types of diseases, perhaps due to its demonstrated efficacy as a popular remedy to treat a large number of diseases, namely chronic hepatitis, arthritis, hypertension, hyperlipidemia, insomnia, bronchitis, neoplasia, asthma, gastric ulcer, atherosclerosis, diabetes, debility due to prolonged illness etc [1]. Almost all medicinal properties have been attributed to G. Iucidum and thus, it is known as 'mushroom of immortality' in China, Japan and Korea.

Ganoderma spp. occur in morphological types such as black, light black, red, purple, yellow and white. Each type of Ganoderma has its own characteristic biological properties. The commonly used medicinal Ganoderma include G. Iucidum, G. tsuge, G. capense and $G$. applanatum. The fruiting bodies of $G$. Iucidum contain a variety of chemical substances, major components are terpenoids and polysaccharides. Currently 130 triterpenoids, and more than 100 types of polysaccharides are reported from G. lucidum [2].

In biological systems potentially harmful reactive oxygen species (ROS) are produced during the normal aerobic metabolism. Antioxidants are deployed to prevent generation of ROS or to scavenge those formed. Deficiency of antioxidative defenses may lead to oxidative stress, which might be associated with a variety of disorders such as coronary heart diseases, neural disorders, diabetes, arthritis and cancers [3,4]. For chronic diseases, such as osteoarthritis and rheumatoid arthritis, life long dependency on antiinflammatory drugs is necessary. The most widely used non-steroidal antiinflammatory drugs (NSAID) suffer from several side effects. Hence, the search for effective antiinflammatory agents that could be safely used on a long-term basis is a priority [5].

G. Iucidum has been found to occur widely in India particularly in the tropical areas. Previous studies at Amala Cancer Research Centre showed that the methanolic extract of G. Iucidum occurring in tropical South India possessed significant antioxidative and antiinflammatory activities [6],[7]. Some physiological effects and distinctive properties of Ganoderma are strain dependent and evidence for strain specific terpenoids has been reported in this mushroom [8]. In this communication, we report the antioxidative and antiinflammatory activities of the chloroform extract of $G$. lucidum occurring in the tropical South India.

\section{Experimental}

\section{Plant collection and identification}

Fruiting bodies of $G$. lucidum growing on gulmohar trees (Delonix regia Raf.) were collected from the out skirts of Thrissur, Kerala, South India. The specimen was identified by Prof. K.M. Leelavathi ( Dept. of Botany, Calicut University, Calicut, India). A voucher specimen is deposited in the herbarium of Centre for Advanced Studies in Botany, University of Madras, Chennai (HERB.MUBL-3172). 


\section{Phytochemical procedures}

\section{Preparation of extract}

Fruiting bodies of the mushroom were cut into small pieces, dried at $45-50^{\circ} \mathrm{C}$ for $48 \mathrm{~h}$ and powdered. The powdered material $(200 \mathrm{~g})$ was extracted with petroleum ether using a Soxhlet apparatus for $24 \mathrm{~h}$. The defatted material was then extracted with chloroform by the same process. The chloroform extract was evaporated to dryness at $40^{\circ} \mathrm{C}$ using a rotary vacuum evaporator. The residue $(3 \mathrm{~g})$ thus obtained was used for the experiments.

\section{Phytochemical screening}

Phytochemical screening for secondary metabolites in the chloroform extract was carried out by Mayer's and Dragendorff's tests (alkaloids), Shinoda's test (flavonoids), ethanolic $\mathrm{KOH}$ test (coumarins), Libermann-Burchard test (terpenoid/steroids) and froth formation test (saponins) [9-11]. The chloroform extract of G. lucidum dissolved in chloroform and applied onto the silica gel HPTLC plate (60 F 254, E. Merck, Germany, $10 \times 10 \mathrm{~cm}$ ) as 6 $\mathrm{mm}$ wide bands with an automatic Linomat $\mathrm{V}$ applicator with $\mathrm{N}_{2}$ flow (Camag, Switzerland). The HPTLC plate was developed to a height of $80 \mathrm{~mm}$ in hexane-chloroform-methanol $(1.5: 7.5: 1)$ with pre-saturation for $15 \mathrm{~min}$. in a Camag twin trough glass tank. After development, the plate was derivatized in anisaldehyde-sulfuric acid, dried and spots were visualized in white light and scanned at $580 \mathrm{~nm}$ (visible, tungston lamp) using Camag TLC Scanner 3 equipped with Wincat software at slit width $5 \times 0.45 \mathrm{~mm}$.

\section{Pharmacological evaluation}

\section{Determination of antioxidant activity}

In vitro antioxidant activity of the extract was determined by DPPH (1,1 diphenyl 2-picryl hydrazyl) scavenging activity using AEAC (Ascorbic acid equivalent antioxidant capacity) as standard. AEAC is the concentration of ascorbic acid required to give the same antioxidant capacity as test substance [12]. Superoxide radical, lipid peroxidation and nitric oxide scavenging activities of the extract were determined by finding out $\mathrm{IC}_{50}$ values.

\section{DPPH radical scavenging activity}

In this method DPPH (2,2-diphenyl-1-picrylhydrazyl) dissolved in methanol was used [13].

\section{Superoxide anion scavenging activity}

Superoxide anion scavenging activity was determined according to the method of McCord and Fridovich (1969) [14]. Quercetin was used as standard.

\section{Inhibition of lipid peroxidation}

Lipid peroxidation induced in rat liver homogenate [15] and its inhibition by the extract was determined by the method of Ohkawa et al. [16]. Ascorbic acid was used as standard.

\section{Nitric oxide scavenging activity}

Nitric oxide scavenging activity was determined by the method of Sreejayan and Rao (1997) [17]. Quercetin was used as standard. 


\section{Determination of antiinflammatory activity}

Acute and chronic antiinflammatory activities of the extracts were evaluated by carrageenan-induced acute and formalin-induced chronic inflammatory models in mice. The extract was administered orally.

\section{Carrageenan-induced paw edema}

Male Swiss albino mice were divided into four groups of six animals in each group. In all groups the inflammation was induced by single sub-plantar injection of $20 \mu \mathrm{l}$ of freshly prepared $1 \%$ carrageenan suspension in normal saline [18]. Group 1 treated with carrageenan alone served as control. Group 2 and 3 received G. lucidum extract at concentrations of 50 and $100 \mathrm{mg} / \mathrm{kg}$ body wt. orally $1 \mathrm{~h}$ before the carrageenan injection. The extract was presolubilized in $0.2 \%$ dimethyl sulfoxide (DMSO) and a fine suspension was prepared in phosphate buffered saline. Group 4 was administered with reference drug diclofenac $(10 \mathrm{mg} / \mathrm{kg}$ body weight) also orally $1 \mathrm{~h}$ before carrageenan injection [18]. The paw thickness of animals in all groups was measured using vernier calipers before and $3 \mathrm{~h}$ after carrageenan injection.

\section{Formalin - induced paw edema}

Experimental procedure was the same as described above except that single dose of $0.02 \mu \mathrm{l}$ of formalin $(2 \%)$ was used to induce inflammation [18]. The extract was administered once daily for 6 consecutive days [19].

In the above two models, the degree of edema formation was determined as increase in paw thickness. In the case of acute anti-inflammatory activity, paw thickness was measured once daily for 6 days. The increase in paw thickness and percent inhibition were calculated as follows.

Increase in paw thickness in control/treatment $\quad \frac{P_{c}}{P_{T}}=P_{t}-P_{0}$

$$
\text { Percent inhibition }=\left(\frac{P_{c}-P_{T}}{P_{c}}\right) \cdot 100
$$

Where $P_{t}$ is paw thickness at time $t, P_{o}$ is initial paw thickness, $P_{c}$ is the increase in paw thickness of the control group and $\mathrm{P}_{\mathrm{T}}$ is the increase in paw thickness of the treatment groups [16].

\section{Animal Experiments}

All animal experiments were carried out according to the guidelines of the Committee for the Purpose of Control of Experiments on Animals (Reg. No. 149/1999/CPCSEA) and approval of the Institutional Animal Ethics Committee was obtained.

\section{Statistical analysis}

Experimental data are expressed as mean \pm SD. Student's $t$ test was applied for expressing the significance and $P$ value less than 0.05 was considered as significant. 


\section{Results}

\section{Phytochemical screening}

The chloroform extract of G. Iucidum was tested positive for terpenoids and alkaloids in preliminary phytochemical tests. The HPTLC fingerprint of the chloroform extract is shown in Fig. 1.

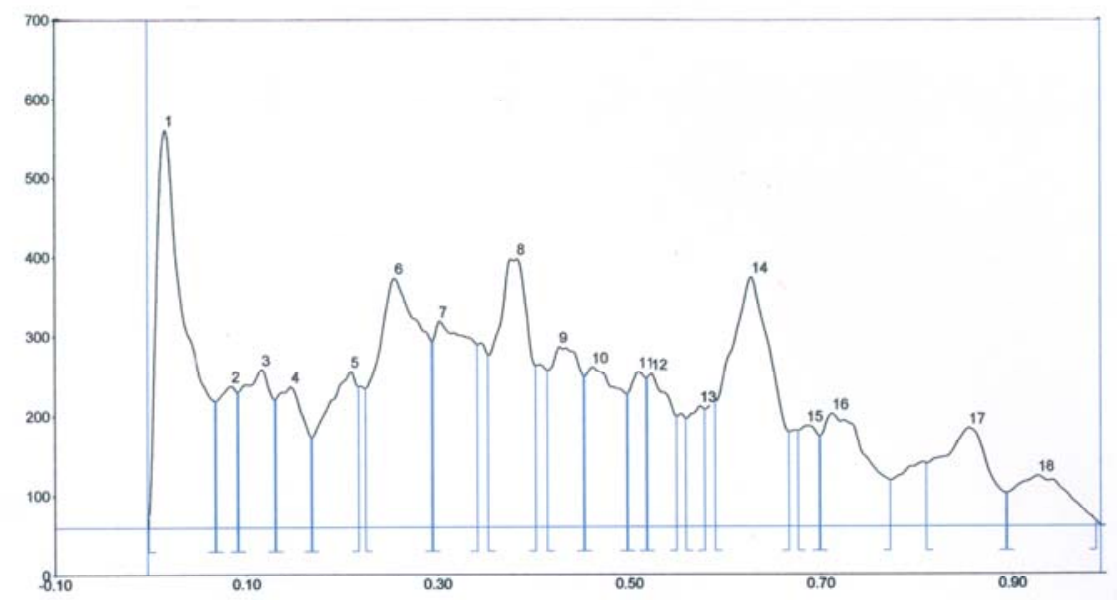

Fig. 1. HPTLC profile of the chloroform extract of $G$. lucidum in $1.5: 7.5: 1$ hexanechloroform-methanol, derivatized in anisaldehyde-sulfuric acid and scanned at $580 \mathrm{~nm}$.

\section{Antioxidant capacity of extract: DPPH radical scavenging activity}

The results showed that the chloroform extract of G. lucidum showed potent radical scavenging activity. The activity of the extract at different concentrations is presented in Table 1 . The result indicated free radical scavenging activity of the extract in a dose dependent manner.

\section{Superoxide radical scavenging activity}

The chloroform extract of G. Iucidum was found to scavenge superoxide generated by photoreduction of riboflavin (Table 2). The extract showed significant superoxide scavenging activity $\left(\mathrm{IC}_{50}: 144.6 \pm 1.5 \mu \mathrm{g} / \mathrm{ml}\right)$.

\section{Inhibition of lipid peroxidation}

Chloroform extract of $G$. lucidum was effective in inhibiting the lipid peroxidation induced by $\mathrm{Fe}^{2+}$-ascorbate system in rat liver homogenate (Table 2). The generation of malondialdehyde (MDA) and related substances that react with thiobarbituric acid (TBARS) was found to be inhibited by the extract. This indicated lipid peroxidation inhibiting activity of the extract $\left(\mathrm{IC}_{50}: 593.3 \pm 25.1 \mu \mathrm{g} / \mathrm{ml}\right)$. 


\section{Nitric oxide radical scavenging activity}

The chloroform extract of $G$. lucidum effectively reduced the generation of nitric oxide radicals from sodium nitroprusside solution (Table 2). This showed marked nitric oxide scavenging activity of the extract $\left(\mathrm{IC}_{50}: 21.6 \pm 1.5 \mu \mathrm{g} / \mathrm{ml}\right)$.

Tab. 1. Free radical scavenging activity of chloroform extract of $G$. lucidum by DPPH reduction:

\begin{tabular}{ll}
\hline Concentration $(\mu \mathrm{g} / \mathrm{ml})$ & Radical scavenging $(\%)$ \\
\hline 100 & $24.46 \pm 1.14$ \\
300 & $58.81 \pm 3.79$ \\
500 & $72.86 \pm 1.30$ \\
700 & $83.77 \pm 1.82$ \\
1000 & $91.12 \pm 1.10$ \\
Ascorbic acid $(100 \mu \mathrm{M})$ & $95.55 \pm 0.98$ \\
\hline \multicolumn{2}{l}{ Values are mean \pm SD., $\mathrm{n}=5$}
\end{tabular}

Tab. 2. In vitro antioxidant activity of chloroform extract of G.lucidum $\left(\mathrm{IC}_{50} \mu \mathrm{g} / \mathrm{ml}\right)$

\begin{tabular}{cccc}
\hline Activities & $\begin{array}{l}\text { Chloroform } \\
\text { extract }\end{array}$ & $\begin{array}{l}\text { Ascorbic acid } \\
\text { (Standard) }\end{array}$ & $\begin{array}{l}\text { Quercetin } \\
\text { (Standard) }\end{array}$ \\
\hline $\begin{array}{c}\text { Superoxide } \\
\text { scavenging }\end{array}$ & $144.66 \pm 1.52$ & & $3.7 \pm 0.16$ \\
$\begin{array}{c}\text { Lipid peroxidation } \\
\text { inhibiting } \\
\text { Nitric oxide } \\
\text { scavenging }\end{array}$ & $593.33 \pm 25.1$ & $900 \pm 15.0$ & \\
\hline Values are mean \pm SD., $\mathrm{n}=5$ & & $500 \pm 21$ \\
\hline
\end{tabular}

\section{Anti-inflammatory activity}

The chloroform extract of $G$. lucidum showed significant inhibitory effect against induced inflammation in both the experimental models. The carrageenan induced acute and formalin induced chronic inflammation were significantly inhibited by the extract. The effect was evident from the inhibition of the paw edema ( Fig. 2).

The effect was significantly high in $100 \mathrm{mg} / \mathrm{kg}$ body wt. extract treated group compared with standard reference drug, diclofenac. The carrageenan induced paw edema was reduced by $73.4 \%$ and $63.2 \%$ with treatment of chloroform extract of G. lucidum at concentrations of 100 and $50 \mathrm{mg} / \mathrm{kg}$ body weight respectively compared to that of the control group. Where as the inhibitory effect was $63.4 \%$ and $53.4 \%$ for formalin induced paw edema with the treatment of the extract at 100 and $50 \mathrm{mg} / \mathrm{kg}$ body weight respectively. Standard reference drug diclofenac showed an inhibition of $53.0 \%$ and $40.2 \%$ of carrageenan and formalin induced inflammation respectively (Fig. 2). 


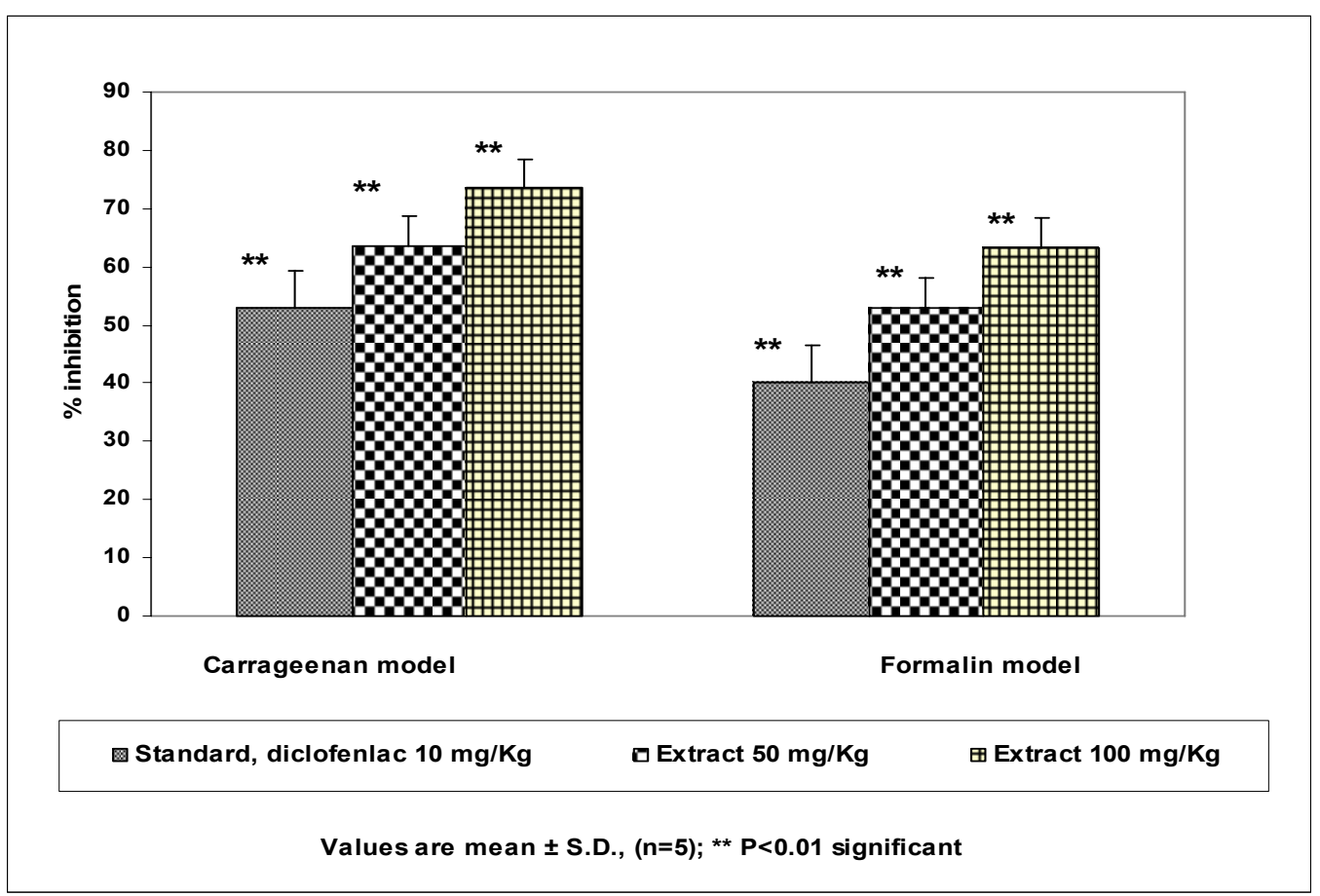

Fig. 2. Inhibition of acute and chronic inflammation by chloroform extract of G.lucidum (50 and $100 \mathrm{mg} / \mathrm{kg}$ ) administered orally.

\section{Discussion}

The results of the present investigation reveal that chloroform extract of $G$. lucidum possesses significant capacity to inhibit free radical formation and scavenging activity. The extract acts at two different levels as primary antioxidant. Antioxidants show activities at different level of protection [20]. Although organisms are bestowed with antioxidant and repair systems that have evolved to protect them against oxidative damage, these systems are insufficient to prevent the damage totally [21]. Hence antioxidants in diet are of great importance as possible protective agents to help human body to reduce oxidative damage. Recently a large number of natural antioxidants have been isolated from different plants. [22-24]. Mushrooms are functional food and are traditionally used in folk medicine in several countries. Human diet containing medicinal mushrooms possessing antioxidative properties would be potentially useful to help human body to reduce oxidative damage. The broad-spectrum medicinal property of $G$. lucidum might be due its significant antioxidantive activity. Our earlier reports also confirm this conclusion [6, 25].

In the DPPH assay, the ability of antioxidant to scavenge stable purple-colored primary radical DPPH is tested by its depolarization spectrophotometrically at $515 \mathrm{~nm}$ [13]. This shows the ability of the extract to scavenge stable free radicals.

The chloroform extract of $G$. Iucidum shows significant superoxide anion, nitric oxide scavenging and lipid peroxidation inhibiting activity in a dose dependent manner. Simultaneous generation of $\mathrm{NO}$ an $\mathrm{O}_{2}^{-}$favours the production of a toxic reaction product, peroxynitrite $\left(\mathrm{ONOO}^{-}\right)$[26]. The scavenging of the superoxide anion generated from the photoreduction of the riboflavin and nitric oxide from sodium nitroprusside indicate the possibility of preventing the peroxynitrite formation in the cell. Reducing the nitric oxide 
generation in the digestive tract was found to be effective in preventing the reactions of nitrate with amines and amides to form carcinogenic nitrosamines and nitrosamides [27]. Hence the NO scavenging activity of G. lucidum extract could play a preventive role against nitrosamine mediated carcinogenesis.

The anti-inflammatory activity of chloroform extract of G. lucidum is dose dependent. Carrageenan induced acute inflammation in animals is one of the most suitable test procedures to screen anti-inflammatory agents. The carrageenan induced edema is mediated by activation of platelet activating factor (PAF), prostaglandins and other inflammatory mediators [28]. The first phase is attributed to the release of histamine 5-HT and kinins. The second phase is related to the release of prostaglandins [29-31]. Carrageenan also induces a protein rich exudate containing large number of neutrophills [32]. Formalin induced paw edema is also one of the most suitable test procedure to screen chronic anti-inflammatory agents as it closely resembled human arthritis [33]. The nociceptive effect of formalin is also biphasic, an early neurogenic component followed by tissue mediated response [34].

The preliminary phytochemical analysis reveals that the major chemical constituents of the chloroform extract of $G$. Iucidum are terpenoids. The major chemical components of $G$. lucidum are known to be polysaccharides and triterpenoids [35]. Thus triterpenoids of chloroform extract might be responsible for the antioxidant and inflammatory activities [36]. Kim et al (1999) [37] identified ganoderic acid A, B, G, and $H$, the triterpene component of commercial strain of $\mathrm{G}$. Iucidum, for its antiinflammatory activity.

In conclusion, the chloroform extract of South Indian G. Iucidum exhibited significant antiinflammatory activity in mice. The chloroform extract also possessed significant antioxidative activity. However the findings suggest the therapeutic potentials of the chloroform extract of this mushroom for the prevention and the control of inflammation and diseases mediated through oxidative stress.

\section{Acknowledgements}

The authors express their sincere thanks to the Director, TBGRI and the Director Amala Cancer Research Centre for providing laboratory facilities. Financial support from the Department of Science and Technology (DST), Government of India, New Delhi for these investigations is also gratefully acknowledged.

\section{Authors' Statements}

\section{Competing Interests}

The authors declare no conflict of interest.

\section{Animal Rights}

The institutional and (inter)national guide for the care and use of laboratory animals was followed. See the experimental part for details. 


\section{References}

[1] Jong SC, Birmingham JM.

Medicinal benefits of the mushroom Ganoderma.

Adv Appl Microbiol. 1992; 37: 101-134.

doi:10.1016/S0065-2164(08)70253-3

[2] Wasser SP.

Reishi or Lingzhi (Ganoderma lucidum).

Encyclopedia of Dietary Supplements, Marcel Dekker, Germany. 2005; 603-622.

doi:10.1081/E-EDS-120022119

[3] Yoshikawa T, Toyokuni S, Yamamoto Yand Naito Y., (Eds.)

Free Radicals in Chemistry Biology and Medicine.

OICE International Saint Lucia 2000.

[4] Spiteller G.

Peroxidation of linoleic acid and its relation to aging and age dependent diseases.

Mech Ageing Dev. 2001; 122: 617-657.

doi:10.1016/S0047-6374(01)00220-2

[5] Chen AW.

Cultivation of the medicinal mushroom Ganoderma lucidum (Curt.: Fr.) P. Karst. Reishi in North America.

Mushroom World. 2001; 1-9.

[6] Sheena N, Ajith TA, Janardhanan KK.

Antiinflammatory and antinociceptive activities of Ganoderma lucidum occurring in South India.

Pharm Biol. 2003; 41: 301-304.

doi:10.1076/phbi.41.4.301.15677

[7] Lakshmi B, Tilak JC, Adhikari S, Devasagayam TPA, Janadhanan KK.

Evaluation of antioxidant activity of selected Indian mushrooms .

Pharm Biol 2004; 42: 179-185.

doi:10.1080/13880200490514023

[8] Nishitoba T, Salo H, Shirasu S, Sakamura S.

Evidence on the strain specific terpenoid pattern of Ganoderma lucidum.

Agric Biol Chem. 1986; 50: 2151-2154.

[9] Jun Wu, Yang-Hua Yi, Hai-Feng Tang, Hou- Ming Wu, Zhen-Rong zou, Hou-Wen Lin.

Nobilisides A-C, Three new triterpene glycosides from the Sea Cucumber Holothuria nobilis.

Planta Med. 2006; 72: 932-935.

doi:10.1055/s-2006-931603

[10] Ying-Rui, Yun- Bao Ma, You- Xing Yao, Jun Zho, Ying Zho, Ji-Jun Chen.

Two new quaternary alkaloids and anti-hepatitis B virus active constituents from Corydalis saxicola.

Planta Med. 2007; 73: 787-791.

doi:10.1055/s-2007-981549

[11] Harborne J B.

Phytochemical methods.

Chapman and Hall, London, 1973.

[12] Gil M L, Thomas-Basberan FA, Hess-Pierce B, Holcroft D M, Kader A A.

Antioxidant activity of promegranate juice and its relationship phenolic composition and processing.

J Agr Food Chem. 2000; 48: 4581-4589.

doi:10.1021/jf000404a

[13] Aquino R, Movellis, Lauro MR, Abdo S, Saiju A, Tomaino A.

Phenolic constituents and antioxidant activity of an extract of Anthurium versicolor leaves.

J Nat Prod. 2001; 64: 1019-1023.

doi:10.1021/np0101245 
[14] Mc Cord JM, Fridovich I.

Superoxide dismutase. An enzymatic function for erythrocuprein.

J Biol Chem. 1969; 244: 6049-6055

PMid:5389100

[15] Bishayee S, Balasubramanian AS.

Lipid peroxidation in rat brain.

J Neurochem. 1979; 18: 909-920.

doi:10.1111/j.1471-4159.1971.tb12020.x

[16] Ohkawa H, Ohishi N, Yagi K.

Assay for lipid peroxide in animal tissue by thiobarbituric acid reaction.

Annal Biochem. 1979; 95: 351-358.

doi:10.1016/0003-2697(79)90738-3

[17] Sreejayan M, Rao MNA.

Nitric oxide scavenging by curcuminoids.

J Pharm Pharmacol. 1997; 58: 237-240.

PMid:9120760

[18] Ajith TA, Janardhanan KK.

Antioxidant and anti-inflammatory activities of methanol extract of Phellinus rimosus.

Ind J Exp Biol. 2001; 39: 1166-1169.

PMid:11906113

[19] Nitha B, Meera C R, Janardhanan KK.

Anti-inflammatory and antitumor activities of cultured mycelium of morel mushroom, Morchella esculenta.

Curr Sci. 2007; 92: 235-239.

[20] Cadena E, Packer L, (Eds).

Hand Book of Antioxidants, Plenum Publishers, New York 1996.

[21] Hemnani T, Parihar MS.

Reactive oxygen species and oxidative DNA damage.

Indian J Physiol Pharmacol 1998; 42: 440-452.

PMid:10874342

[22] Packer L, Ong ASH (Eds.).

Biological Oxidants and Antioxidants.

Molecular Mechanisms and Health Effects, AOCS Press, Champaign, IL, 1997.

[23] Jovanovic SV, Simic MG.

Antioxidants in nutrition.

Ann N YAcad Sci. 2000; 899: 326-334.

doi:10.1111/j.1749-6632.2000.tb06197.x

[24] John JH, Ziebland S, Yudkin P, Roe LS, Neil HA.

Effects of fruit and Vegetable consumption on plasma antioxidant concentration and blood pressure: a randomized controlled trial.

Lancet. 2002; 359: 1969-1974.

doi:10.1016/S0140-6736(02)98858-6

[25] Sheena N, Ajith TA., Janardhanan KK.

Protective effect of methanolic extract of Ganoderma lucidum P.Karst. Reishi from South India against doxorubicin-induced cardiotoxicity in rats.

Oriental Pharmacy and Experimental Medicine. 2005; 5: 62-68.

[26] Beckman JS, Beckman TW, Chen J, Marshall PA, Freeman BA.

Apparent hydroxyl radical production by peroxynitrite: implications for endothelial injury from nitric oxide and superoxide.

Proc Natl Acad Sci U S A. 1990; 87: 1620-1623.

PMid:2154753 
[27] Boone CW, Kelloff GJ, Malone WE.

Indentification of candidate cancer chemopreventive agents and their evaluation in animal models and human trails: A Review.

Cancer Res. 1990; 50: 2-9.

PMid:2403415

[28] Hwang S, Lam MLiC, Shen T.

Release of platelet activating factor and its involvement in the first phase of carrageenan rat foot oedema.

Eur J Pharmacol. 1986; 120: 33-41.

doi:10.1016/0014-2999(86)90636-9

[29] Larsen GL, Henson PM.

Mediators of inflammation.

Ann Rev Immunol. 1983; 1: 335-339.

doi:10.1146/annurev.iy.01.040183.002003

[30] Brooks PM, Day RO.

Non steroidal anti-inflammatory drugs: differences and similarities.

N Engl J Med. 1991; 324: 1716-1725.

PMid:2034249

[31] Vane J, Booting R.

Inflammation and the mechanism of action of anti-inflammatory drugs.

FASEB J. 1987; 1: 89-96.

PMid:3111928

[32] Lo TN, Almeida AP, Beaven MA.

Dextran and carrageenan evoke different inflammatory response in rat with respect to composition of infilterates and effect of indometacin.

J Pharmacol Exp Ther. 1982; 21: 221-261.

PMid:6174730

[33] Greenwald RA.

Animal model for evaluation of arthritic drugs.

Meth Find Exp Clin Pharmacol. 1991; 13: 75.

PMid:2072812

[34] Wheelmer-Aceto H, Cowan A.

Neurogenic and tissue mediated components of formalin induced oedema.

Agents Actions. 1991; 34: 264-268.

doi:10.1007/BF01993299

[35] Russell R, Paterson M.

Ganoderma - A therapeutic fungal factory

Phytochemistry. 2006; 67: 1985-2001.

doi:10.1016/j.phytochem.2006.07.004

[36] Zhou Z, Lin J, Yin Y, Zhao J, Sun X, Tang K.

Ganodermataceae: Natural products and their related pharmacological functions.

Amer J Chin Med. 2007; 35: 559-574.

doi:10.1142/S0192415X07005065

[37] Kim HW, Kim BK.

Biomedical triterpenoids of Gandorma lucidum (Curt.: Fr.) P. Karst.(Aphyllophoromycetideae).

Int J Med Mushr. 1999; 1: 121-138. 